\title{
Big Data Confidentiality in Healthcare
}

\author{
Amudha S. Anita Davamani K, N. Priya
}

\begin{abstract}
We exist these days in an overall release, anywhere protection is not really kept up, with the huge information getting included, it's just deteriorating, since information is from this time forward all over and about everybody, we can't generally educate who recognizes what concerning who, where the information is really depending, and what utilizes are through not in of it. Security however a vital angle that individuals dependably require in numerous areas, and it's not less vital in the human services diligence, where data just gets much progressively close to home and touchy that any protection rupture turns into an issue of last chance. In this paper, we have concentrated on the advantages of huge information in the medicinal services segment, just as a portion of the principle challenges regularly experienced. We have then focused on the Moroccan setting, demonstrated the issues it has and its specificities, so as to propose proposals to urge the leaders to take the way of Big Data. Lastly, we have edified the security issues in medicinal services and the present strategies used to guarantee the patient's protection.
\end{abstract}

Keywords:Healthcare,data isolation,capasity

\section{INTRODUCTION}

Cell phones, interpersonal organizations, sensors, keen meter, Internet of things (IoT), [1],[3],[5]Cloud registering, and so forth., are for the most part new advances that make life a lot simpler, by gathering a limit of information about the shoppers, so as to consider benefits completely adjusted to their necessities. Monstrous information is, hence, being delivered on an exponential rate around the world, furthermore, the conventional DBMSs can never again handle this exceptional information development. The medicinal services part depends intensely on restorative information in the basic leadership process, this information comes in numerous shapes plus is accordingly different, [2 ], [ 4],[6]

formless and composite, to the DataBase Management Systems couldn't receive in control in a viable method. Medicinal services diligence has along these lines huge enthusiasm for utilizing large information in training. Despite the fact that the bottomless creation of medicinal in order conveys numerous advantages to the social insurance part, it does likewise raise various difficulties, particularly the security issues. In this paper, we will address the

Revised Manuscript Received on July 22, 2019.

Amudha S, Department of Computer Science and Engineering, Bharath Institute of Higher education and research, Chennai , India

Anita Devamani, Department of Computer Science and Engineering, Bharath Institute of Higher education and research, Chennai , India

N. Priya, Department of Computer Science and Engineering, Bharath Institute of Higher education and research, Chennai , India accompanying focuses: in segment 2, we will show Big Data in medicinal services, [7], [9], [11]

its effect what's more, difficulties and some existing connected works. In segment 3, we will concentrate on the Moroccan setting, its issues and specificities, just as certain suggestions to use Big Data in the Moroccan social insurance area. In area 4, we will introduce the security issue in the medicinal services, the laws overall with respect to the protection and the diverse strategies utilized right now to guarantee the patient's security. We at last close the paper and give what's to come work we intend to continue.

\section{RESULTS \& DISCUSSIONS}

\section{A .Enormous information in Healthcare}

Huge information alludes to enormous volume of information, created at large rates and a major assortment of structures, it depends on a lot of exceptionally performance innovations consolidated together to utilize these uncommon volumes of different and quick information.

\section{B. Consequences and challenge}

Medicinal information source are different, and contain a major investigative latent, they be able to consequently live utilized to give powerful answers for the issues in the social insurance industry. Every one of these sources create huge volume of information at high pace, set the assortment of information produced additionally of huge range. We can along these lines talk about Big Data in the medicinal services part. By utilizing Big Data in human services, a few advantages be able to be in use, including: Improvement of value and adequacy of therapeutic consideration, premature ailment location and recognition of restorative cheats. One viable case of the helpfulness of Big Data advances in the medicinal services division be accumulation and collection of different extensive information coming from therapeutic source and somewhere else on the system's edge, process and examine it progressively, so as to show signs of improvement comprehension of the spreading of certain sorts of infections inside a known populace, [20],[22], [24] so as to be a stage in front and obtain the essential actions toward end its scattering. Google's influenza pattern perhaps the majority model known in the utilization of Big Data to show signs of improvement bits of knowledge to upgrade the medicinal services. Despite the fact that medicinal services industry has huge enthusiasm for utilizing huge information, it has falled behind the various businesses in getting bits of knowledge from these new advances. [13], [15], [ 17]

This is for the most part because of various difficulties that moderate down the way toward executing Big Data in social insurance, counting: the patient's protection problem, the industry status, the need in IT framework in addition to 
engineering, plus the vital inquiry of the restorative information possession,

\section{Related work}

A few nations are in receipt of their foot damp in receiving experiences from gigantic information in medicinal division. [26],[28],[30]

In the United-States, effective activities cover risen, for instance, the Indiana Health Information Exchange, which is a non-benefit association to facilitate gives protected with strong wellbeing data innovation arrange associating more than 90 medical clinics, long haul care offices, restoration focuses, network wellbeing centers and other human services suppliers in Indiana. It empowers therapeutic data to pursue the patient as opposed to being housed in one doctor office or a solitary clinic framework. Another model, in Canada,bthe newborn child clinic of Toronto, huge information investigation is utilized to get better outcomes for baby inclined to perilous medical clinic infection. The European nation have some fruitful huge information activities also, in Italy, the Italian Medicines Agency gathers and breaks down clinical information on costly new medications as a major aspect of a national cost-adequacy program; in view of the outcomes, it might reconsider drugs costs and market-get to conditions

\section{MOROCCAN SETTING}

\section{Issues and specificities:}

The human services division in Morocco experiences numerous issues and have, in the other hand, numerous functions including: [37],[39],[41]

A development in populace matured more than 60 years, because of the tremendous fruitfulness and mortality decrease, prompting a sharp increment popular for overwhelming medicinal consideration to take in control incessant and degenerative ailments. The general wellbeing uses are expanding quite a long time after year. As indicated by the National Health Account, in 2010, complete spending on human services spoke to $6.2 \%$ of GDP against $5.3 \%$ in 2006. A deficiency of HR, as per the World Health Organization, Morocco is situated among the 58 nations on planet experiencing an incredible absence of restorative staff. The quantity of introduced medical clinics in Morocco has expanded throughout the most recent 5 decades, achieving 142 open emergency clinics, 7910 private counseling rooms in 2010. [26],[28],[30]

In any case, $58 \%$ of the organizations situated in enormous tomahawks of nation, causing an irregularity among locales and a low complementarily between the private and open areas. Social insurance area in morocco is imperative segment, and wants to develop in viable manner, it is hence, very prescribed the legislature, alongside clergyman of wellbeing with the majority of the human services associations in the nation work together so as to set up useful Big information frameworks.

\section{E. Recommendations:}

It has now turned out to be unavoidable to run with the worldwide mechanical stream, particularly in the human services industry, where effectiveness and precision are the most required. The Moroccan social insurance needs to exploit all the innovative advances so as to improve its everyday practice while upgrading the nature of Medicare and - for the most part the patient's security. Following are a few proposals to use Big Data in the Moroccan medicinal services area.

\section{F. Technological :}

Study and plan a develop IT framework, to help the diverse details and limitations in the Moroccan medicinal services part. Since most of human services associations in Morocco don't have ICT frameworks, every one of the tasks connected to the medicinal information are done physically, which happens in tremendous misfortunes of significant information, futile information excess, and multifaceted nature in information examination.. Put resources into data trade organizes so as to stay away from finding and treatment excess, by enabling clinicians to get fundamental data about the treatment that a patient has gotten from another clinician likewise recorded in the framework.

\section{G .Human:}

In each industry, the human capital assumes an indispensable job, it is subsequently imperative, so as to build up a practical electronic medicinal services foundation, to qualify the neighborhood skills through intermittent preparing programs. [38],[40],[42]

Put resources into mindfulness battles so as to raise cognizance about the advantages of huge information in human services through the association meetings and workshops on a national dimension. Put resources into creating human abilities who can work with information and get bits of knowledge from it, for example, Data researchers, Data chiefs and System supervisors.

\section{H. Legislative and Strategic:}

In the event that an e-Heath framework is set up, authoritative and key structures should be set up, so as to institutionalize the electronic medicinal services practice, to ensure its effectiveness, and - the most vital thing-to guarantee the therapeutic data security and the patient's protection. This should be possible through relevant law, under the Moroccan 09-08 individual data security act. As it were, ponder an e-wellbeing system, so as to completely digitize the human services division, and take the patient-doctor relationship to the following dimension. The foundation an e-wellbeing framework will for sure strikingly improve the Moroccan human services area. [19],[21],[23]

\section{J. Information Privacy in Healthcare}

A standout amongst the most agonizing difficulties over enormous information, is the person's security. We regularly judge security by the apparent damage that may happen if information winds up open. In medicinal services, the damage can be of enormous effect on the person's close to home and expert life. The therapeutic information's protection is the essential aspect that human services adopters of enormous information need to think truly. 
Medicinal services information is progressively digitized, as electronic wellbeing report, therapeutic pictures and doctor notes. Subsequent, are a portion of security insurance law around globe:

\section{H. Canada:}

The Personal Information Protection and Electronic Documents Act, indicates principles to administer accumulation, exposure of individual data. The PIPEDA gives individuals numerous rights, for example, to figure out the reason why associations gather, or reveal individual data, anticipate that associations should ensure the individual data in a sensible and secure way.

\section{European-Union:}

In eighth article of the European Convention on Human Rights, privilege to regard "private and family life, his home and his correspondence" given. The gathering therapeutic information have been made a decision to increase information protection issue. Aware of development and free stream information inside the EU zone, which require all the information security enactment.

\section{M.Data security systems:}

Currently, there are different procedures used to guarantee the patient's protection, the principle ones are:

1) De-distinguishing proof: is a strategy that professes to keep the exposure of classified data, by expelling all recognizing data from restorative records. There are two strategies proposed by the HIPAA to de-distinguish therapeutic data.

Safe-harbor: requires the evacuation of 18 explicit identifiers of the individual or of relatives, bosses or family individuals from the person from the information: names, addresses, dates, phone numbers, fax numbers, wellbeing plan recipient numbers, email addresses, government managed savings numbers, restorative record numbers, account numbers, declaration/permit numbers, vehicle identifiers and sequential numbers, gadget identifiers and sequential numbers, general asset locators (URL), IP addresses, biometric identifiers, full-face photographic pictures, and some other exceptional recognizing number, trademark or code.

Factual technique: an individual with fitting preparing checks sufficient have been expelled.

\section{Observe and assent:}

The enduring has the option to be familiar with and support to how his information will be utilized and by who, by giving him/her notice of an element's data rehearses before gathering any close to home data.

\section{J.Notice and assent successor:}

The patient can willfully pick an outsider and partner themselves with it, so as to acquire a standard arrangement of protection inclination profiles that the human services association can utilize each instance the patient's information should revealed.

K. Removal and non-maintenance: at the point when information is no longer of significant worth, it is a decent practice to erase it. This strategy can be utilized inside human services associations to diminish the protection breaks, yet when enormous information gets included, the inquiry remains which information is of esteem and which information isn't, on the grounds that what is by all accounts valueless today may bring huge esteem tomorrow, in addition, particular the appropriated plus excess natural world of information stockpiling, certification that helpful information have endure the pulverization.

\section{Healthcare Data isolation:}

Security assurance in past contemplated law with strategies for most part held by information controller, the patient never really adds to the development of defense insurance systems. To give a definitive security level inside the social insurance industry in the nation. [31],[33],[35]

M .On the information manager benefit: alludes toward characteristic otherwise lawful individual, open specialist, organization or alone or mutually with others decides reasons with methods for handling individual information. The gathering should guarantee that patients' PHI is shielded as of unapproved access with revelation on each phase of the information's lifecycle (for example Generation, devastation). This can be cultivated through specialized and hierarchical instruments.

Sharing: The information spread ought to perform such diminishes to maximum information spillage hazard, and consistence with both neighborhood with outside nation's information insurance laws, so as to ensure that no information protection ruptures would happen. Information need likewise to be encoded. In huge information however, customary cryptographic calculations are very little proficient, some cryptographic ways can be utilized in the huge information conditions, for example, "character based encryption" with "quality based encryption".

Capacity : the information was not exceptionally touchy, the social insurance couldn't bear the cost of the capacity cost, the cloud stays advantageous to accumulate the therapeutic information however the safety and protection levels will be undermined. In event that the information is profoundly touchy, the information stockpiling is exceedingly prescribed to be inside the wellbeing association, in a private cloud or in another protected area. Information ought to likewise be copied and upheld up - to a specific utmost in another protected area, on the off chance that the first information is harmed.

Chronicle/Destruction: Chronicle is critical, especially in the medicinal services case, where filed information

could be of extraordinary use in the restorative future examines, yet now and again, keeping up the information can be progressively destructive to the association and patient's security, is the reason, is important to controller the genuine estimation of information, so as to realize when to keep up to dispose of it.

\section{N. Topic sake:}

The topic is the one who'll hurt the majority of the protection will not regarded sufficient, as a result likewise comprehend add to security assurance strategy inside the association that has his information. To do as such, we have felt that it is helpful to host a third get-together between the patient and the information controller; who will manage and institutionalize the manner in which individual wellbeing 
data be utilized, during propose a few patient protection profile (e.g., profile contains security inclinations), disseminating on all medicinal services associations in nation. In order imagine how it functions, we have projected the method cry.

Known the aptitude in domain, The Moroccan information security specialist could increase centered around medicinal services part, considering a few protection inclinations profile clinics could convey to any patient who presents himself to medical clinic's gathering or a relative on the off chance that the patient any sort of paper. The patient peruse in detail security insurance profile, with the assistance of counsel, completely mindful of protection ramifications of each proviso in the report.

The patient at that point endorse to partner with the security insurance profile. The medical clinic or social insurance association will send patient's security profile to the CNDP to add it to the profiles database. Expect all emergency clinics contain practical e-wellbeing frameworks, patient then novel in database, with one unmistakable code the nation on the off chance that he picks one protection report, it would be embraced wherever the patient go.

\section{CONCLUSION AND PERSPECTIVES}

The Big Data conveys with enormous guarantees to get better medicinal services division in progressive manner, in any case, a few difficulties and issue contain distinguished significant obstructions utilizing Big Data in social insurance business, primarily protection challenge. In this work, we anticipated light on a portion of the advantages of Big Data in human services segment, different difficulties consider, just as few fruitful connected precedents as of everywhere throughout the world. After that centered around the Moroccan setting, by giving a portion of human services issue and specificities, and include suggestions. The protection be a standout amongst the most vital things that patients demand, displayed the present strategies used to guarantee the patient's security in medicinal services hard work, just as enactment with respect to the protection issues on the planet. We plan, from that point, to concentrate extra on the safety measures and protection parts with restorative information in a Big Data condition, as patients and partners in human services segment are worried regarding the likelihood of guaranteeing better social insurance value dependent on Big Data advancements while ensuring medicinal information safety and patient's protection.

\section{REFERENCES}

A., Rangarajan K.,Algorithm for automaton specification for exploring dynamic labyrinths,Indian Journal of Science and Technology,V-6,I-SUPPL5,PP-4554-4559,Y-2013

[2] P. Kavitha, S. Prabakaran "A Novel Hybrid Segmentation Method with Particle Swarm Optimization and Fuzzy C-Mean Based On Partitioning the Image for Detecting Lung Cancer" International Journal of Engineering and Advanced Technology (IJEAT) ISSN: 2249-8958, Volume-8 Issue-5, June 2019

[3] Kumaravel A., Meetei O.N.,An application of non-uniform cellular automata for efficient cryptography,2013 IEEE Conference on Information and Communication Technologies, ICT 2013,V-,I-,PP-1200-1205,Y-2013

[4] Kumarave A., Rangarajan K.,Routing alogrithm over semi-regular tessellations,2013 IEEE Conference on Information and Communication Technologies, ICT 2013,V-,I-,PP-1180-1184,Y-2013

[5] P. Kavitha, S. Prabakaran "Designing a Feature Vector for Statistical

Texture Analysis of Brain Tumor" International Journal of Engineering and Advanced Technology (IJEAT) ISSN: 2249-8958, Volume-8 Issue-5, June 2019

[6] Dutta P., Kumaravel A.,A novel approach to trust based identification of leaders in social networks,Indian Journal of Science and Technology,V-9,I-10,PP--,Y-2016

[7] Kumaravel A., Dutta P.,Application of Pca for context selection for collaborative filtering,Middle - East Journal of Scientific Research,V-20,I-1,PP-88-93,Y-2014

[8] Kumaravel A., Rangarajan K.,Constructing an automaton for exploring dynamic labyrinths,2012 International Conference on Radar, Communication and Computing, ICRCC 2012,V-,I-,PP-161-165,Y-2012

[9] P. Kavitha, S. Prabakaran "Adaptive Bilateral Filter for Multi-Resolution in Brain Tumor Recognition" International Journal of Innovative Technology and Exploring Engineering (IJITEE) ISSN: 2278-3075, Volume-8 Issue-8 June, 2019

[10] Kumaravel A.,Comparison of two multi-classification approaches for detecting network attacks, World Applied Sciences Journal,V-27,I-11,PP-1461-1465,Y-2013

[11] Tariq J., Kumaravel A.,Construction of cellular automata over hexagonal and triangular tessellations for path planning of multi-robots,2016 IEEE International Conference on Computational Intelligence and Computing Research, ICCIC 2016,V-,I-,PP--,Y-2017

[12] Sudha M., Kumaravel A.,Analysis and measurement of wave guides using poisson method,Indonesian Journal of Electrical Engineering and Computer Science,V-8,I-2,PP-546-548,Y-2017

[13] Ayyappan G., Nalini C., Kumaravel A.,Various approaches of knowledge transfer in academic social network, International Journal of Engineering and Technology,V-,I-,PP-2791-2794,Y-2017

[14] Kaliyamurthie, K.P., Sivaraman, K., Ramesh, S. Imposing patient data privacy in wireless medical sensor networks through homomorphic cryptosystems 2016, Journal of Chemical and Pharmaceutical Sciences 92.

[15] Kaliyamurthie, K.P., Balasubramanian, P.C. An approach to multi secure to historical malformed documents using integer ripple transfiguration 2016 Journal of Chemical and Pharmaceutical Sciences 92.

[16] A.Sangeetha,C.Nalini,"Semantic Ranking based on keywords extractions in the web", International Journal of Engineering \& Technology, 7 (2.6) (2018) 290-292

[17] S.V.GayathiriDevi,C.Nalini,N.Kumar,"An efficient software verification using multi-layered software verification tool "International Journal of Engineering \& Technology, 7(2.21)2018 454-457

[18] C.Nalini,ShwtambariKharabe,"A Comparative Study On Different Techniques Used For Finger - Vein Authentication", International Journal Of Pure And Applied Mathematics, Volume 116 No. 8 2017, 327-333, Issn: 1314-3395

[19] M.S. Vivekanandan and Dr. C. Rajabhushanam, "Enabling Privacy Protection and Content Assurance in Geo-Social Networks", International Journal of Innovative Research in Management, Engineering and Technology, Vol 3, Issue 4, pp. 49-55, April 2018.

[20] Dr. C. Rajabhushanam, V. Karthik, and G. Vivek, "Elasticity in Cloud Computing", International Journal of Innovative Research in Management, Engineering and Technology, Vol 3, Issue 4, pp. 104-111, April 2018.

[21] K. Rangaswamy and Dr. C. Rajabhushanamc, "CCN-Based Congestion Control Mechanism In Dynamic Networks", International Journal of Innovative Research in Management, Engineering and Technology, Vol 3, Issue 4, pp. 117-119, April 2018.

[22] Kavitha, R., Nedunchelian, R., "Domain-specific Search engine optimization using healthcare ontology and a neural network backpropagation approach", 2017, Research Journal of Biotechnology, Special Issue 2:157-166

[23] Kavitha, G., Kavitha, R., "An analysis to improve throughput of high-power hubs in mobile ad hoc network", 2016, Journal of Chemical and Pharmaceutical Sciences, Vol-9, Issue-2: 361-363

[24] Kavitha, G., Kavitha, R., "Dipping interference to supplement throughput in MANET" , 2016, Journal of Chemical and Pharmaceutical Sciences, Vol-9, Issue-2: 357-360

[25] Michael, G., Chandrasekar, A.,'Leader election based malicious detection and response system in MANET using mechanism design approach", Journal of Chemical and Pharmaceutical Sciences(JCPS) Volume 9 Issue 2, April - June 2016.

[26] Michael, G., Chandrasekar, A.,"Modeling of detection of camouflaging worm using

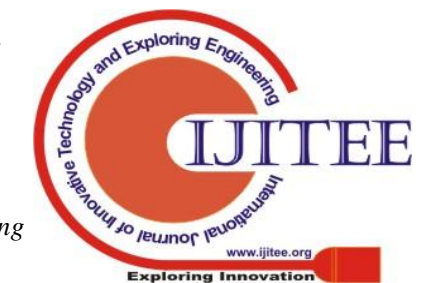


epidemic dynamic model and power spectral density", Journal of Chemical and Pharmaceutical Sciences(JCPS) Volume 9 Issue 2, April June 2016 .

[27] Pothumani, S., Sriram, M., Sridhar, J., Arul Selvan, G., Secure mobile agents communication on intranet,Journal of Chemical and Pharmaceutical Sciences, volume 9, Issue 3, Pg No S32-S35, 2016

[28] Pothumani, S., Sriram, M., Sridhar, Various schemes for database encryption-a survey, Journal of Chemical and Pharmaceutical Sciences, volume 9, Issue 3, Pg NoS103-S106, 2016

[29] Pothumani, S., Sriram, M., Sridhar, A novel economic framework for cloud and grid computing, Journal of Chemical and Pharmaceutical Sciences, volume 9, Issue 3, Pg No S29-S31, 2016

[30] Priya, N., Sridhar, J., Sriram, M. "Ecommerce Transaction Security Challenges and Prevention Methods- New Approach" 2016 ,Journal of Chemical and Pharmaceutical Sciences, JCPS Volume 9 Issue 3.page no:S66-S68 .

[31] Priya, N.,Sridhar,J.,Sriram, M.“Vehicular cloud computing security issues and solutions" Journal of Chemical and Pharmaceutical Sciences(JCPS) Volume 9 Issue 2, April - June 2016

[32]

[33] Priya, N., Sridhar, J., Sriram, M. "Mobile large data storage security in cloud computing environment-a new approach" JCPS Volume 9 Issue 2. April - June 2016

[34] Anuradha.C, Khanna.V, "Improving network performance and security in WSN using decentralized hypothesis testing "Journal of Chemical and Pharmaceutical Sciences(JCPS) Volume 9 Issue 2, April - June 2016.

[35] Anuradha.C, Khanna.V, "A novel gsm based control for e-devices" Journal of Chemical and Pharmaceutical Sciences(JCPS) Volume 9 Issue 2, April - June 2016

[36] Anuradha.C, Khanna.V, "Secured privacy preserving sharing and data integration in mobile web environments " Journal of Chemical and Pharmaceutical Sciences(JCPS) Volume 9 Issue 2, April - June 2016.

[37] Sundarraj, B., Kaliyamurthie, K.P. Social network analysis for decisive the ultimate classification from the ensemble to boost accuracy rates 2016 International Journal of Pharmacy and Technology 8

[38] Sundarraj, B., Kaliyamurthie, K.P. A content-based spam filtering approach victimisation artificial neural networks 2016 International Journal of Pharmacy and Technology 83 .

[39] Sundarraj, B., Kaliyamurthie, K.P. Remote sensing imaging for satellite image segmentation 2016 International Journal of Pharmacy and Technology $8 \quad 3$.

[40] Sivaraman, K., Senthil, M. Intuitive driver proxy control using artificial intelligence 2016 International Journal of Pharmacy and Technology $8 \quad 4$.

[41] Sivaraman, K., Kaliyamurthie, K.P. Cloud computing in mobile technology 2016 Journal of Chemical and Pharmaceutical Sciences 92.

[42] Sivaraman, K., Khanna, V. Implementation of an extension for browser to detect vulnerable elements on web pages and avoid click jacking 2016 Journal of Chemical and Pharmaceutical Sciences 92.

\section{AUTHORS PROFILE}

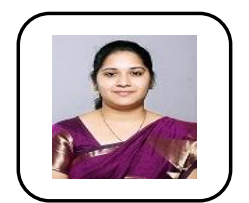

S. Amudha Assistant Professor, Department of Computer Science \& Engineering, Bharath Institute of Higher Education and Research, Chennai, India

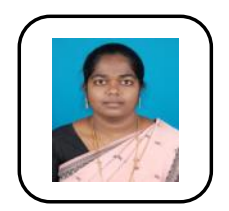

Anitha Devamani, Assistant Professor, Department of Computer Science \& Engineering, Bharath Institute of Higher Education and Research, Chennai, India

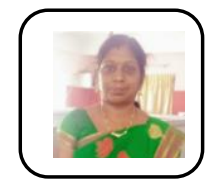

N.Priya, Assistant Professor, Department of Computer Science \& Engineering, Bharath Institute of Higher Education and Research, Chennai, India 